\author{
Martina Ireinová \\ Ústav pro jazyk český Akademie věd České republiky \\ Dialektologické oddělení \\ Brno \\ ORCID: 0000-0002-7112-9827; e-mail: ireinova@ujc.cas.cz
}

\title{
Úkoly české dialektologie na počátku 21. století
}

\begin{abstract}
Abstrakt: Pracovníci dialektologického oddělení Ústavu pro jazyk český Akademie věd České republiky se zabývají výzkumem tradičních teritoriálních dialektů v českém národním jazyce. Vypracovali šest svazků Českého jazykového atlasu (knižně vydáno v letech 1992-2011), dostupný je též v elektronické podobě. Čeští dialektologové zpracovávají Slovnik nářč̌i českého jazyka a Slovník pomistních jmen na Moravě a ve Slezsku. Spolupracují na jednotlivých svazcích Evropského jazykového atlasu (Atlas linguarum Europae) a Slovanského jazykového atlasu (Общеславянский лингвистический атлас).
\end{abstract}

Klíčová slova: dialektologie, dialekty, jazykový zeměpis, jazykový atlas, nářeční slovník.

\begin{abstract}
The tasks of Czech Dialectology at the beginning of the $21^{\text {st }}$ century. The researchers from the Department of Dialectology of the Czech Language Institute of the Czech Academy of Sciences have been involved in research into traditional territorial dialects within the Czech national language. They have compiled six volumes of the Czech Linguistic Atlas (published in 1992-2011) while its electronic version is being finalised. Czech dialectologists have been compiling the Dictionary of Czech Dialects and the Dictionary of Minor Place Names in Moravia and Silesia. They collaborate on the individual volumes of the Linguistic Atlas of Europe (Atlas linguarum Europae) and the Slavic Linguistic Atlas (Общеславянский лингвистический атлас).
\end{abstract}

Keywords: dialectology, dialects, geolinguistics, linguistic atlas, dialect dictionary.

Jediným akademickým pracovištěm v Česku, které se systematicky zabývá zkoumáním nespisovných útvarů českého národního jazyka - zejména problematikou tradičních teritoriálních dialektů - je dialektologické oddělení Ústavu pro jazyk český Akademie věd České republiky, v. v. i., v Brně. Brněnští dialektologové se věnují vlastním projektům, spolupracují s dalšími akademickými a univerzitními pracovišti a podílí se na plnění úkolů mezinárodních projektů.

Mnohé z projekti̊ mají své počátky v době, kdy se při excerpci a zpracovávání shromážděného nářečního materiálu používaly pouze pero, tužka, psací stroj a při mapování šablona. Dnes je samožrejmostí práce s počítačem: pro zpracování slovníkových hesel využívají dialektologové elektronické formuláře a pro tvorbu jazykových map speciální počítačové programy. Nezbytnou součástí vědecké práce vždy byla a je prezentace výsledků, nestačí však publikovat v odborném tisku, vystupovat na vědeckých konferencích, důležité je zpř́ístupňovat výsledky práce co nejširšímu publiku odbornému i laickému, 
umožnit využití vědeckých poznatků při výuce na základních, středních i vysokých školách. Místem, odkud se informace dostanou k velkému počtu percipientů, je internet. Dialektogové tedy zveřejňují své výstupy na webových stránkách, prostřednictvím internetu jsou v kontaktu se zájemci o nářečí a také sledují laické aktivity zaměřené na prezentace charakteristických lokálních nářečních rysů a nářečních diferencí1.

Jedním z velkých projektů české dialektologie je šestidílný Český jazykový atlas (dále ČJA), který představuje na 1558 mapách (a v 1578 komentářích) první úplný obraz územního rozrůznění českého národního jazyka. Byl připravován již od poloviny 60 . let 20. století. Podle Dotazníku pro výzkum českých nářeči (1964-1965), obsahujícího 2649 položek, byl v letech 1964-1972 realizován přímý terénní výzkum ve 420 venkovských lokalitách, mezi něž bylo zařazeno i pět vesnic ležících v dnešním Polsku nedaleko česko-polských hranic, a to dvě ze starého českého osídlení na Kladsku (Słone, Jakubowice) a tři z bývalého opavského Slezska (Branice, Pietrowice Wielkie, Krzanowice). Mimo tuto sít obcí se podle téhož dotazníku zkoumala též nářečí v dalších 13 zahraničních lokalitách obývaných od 18./19. století českými osídlenci a jejich potomky, a to v Polsku (Gęsiniec), v bývalé Jugoslávii (sedm lokalit) a v Rumunsku (pět lokalit). Výzkum se neomezil jen na venkovské prostředí, ale v letech 1973-1976 pokračoval také v 57 městech. Zkoumalo se podle Dotazníku pro výzkum českých nářeči (byly však eliminovány položky zaměřené na venkovské reálie, např. součásti pluhu, cepu) a podle zvláštního lexikálního dotazníku, obsahujícího 139 položek zaměřených na reálie spojené s městským životem (např. tramvaj, biograf); část dotazů byla určena pouze mládeži s cílem zachytit slangové výrazy ze studentského prostředí (např. žvýkačka, školník, školní předmět český jazyk).

První tři svazky ČJA jsou věnovány nářečnímu lexiku, zachycují výrazy, které byly součástí každodenního života na venkově, lidé se $\mathrm{s}$ jejich pomocí dorozumívali při práci na poli, v hospodářství, v domácnosti, popisovali jimi okolní prŕrodu. Čtvrtý svazek představuje územní diference forem všech ohebných slovních druhů. Základem pátého svazku je kapitola o vybraných hláskoslovných jevech; zpracovány byly též jevy syntaktické a tvoření adverbií, jsou zde prezentovány výsledky doplňkového výzkumu ve městech a mapy svazků izoglos excerpovaných z celého ČJA (tyto mapy přinášejí nový pohled na členění našich nářečí a zobrazují i dosud nepopsané areály).

Dodatky, šestý svazek ČJA, neobsahují mapy, ale přinášejí informace, které tvoří z ČJA kompletní, ucelené dílo: rejstř́ík nářečních dokladů z ČJA 1-5, rozsáhlý soupis bibliografie české dialektologie od roku 1968, charakteristiky zkoumaných lokalit a dotazníky, podle nichž se nářeční výzkum uskutečnil. Součástí tohoto svazku jsou dvě $\mathrm{CD}$, na nichž je zaznamenáno 70 vyprávění, která byla pořízena během nářečního výzkumu pro ČJA. V Dodatcích jsou k dispozici i přepisy těchto ukázek a stručná charakteristika nářečních jevů v nich obsažených. Posluchač nejen že získá konkrétní představu o zvukové podobě našich nářečí, ale také se z vyprávění dozví, jak se dříve lidem na vesnici žilo, jak hospodařili, jaké udržovali zvyky, jak osobně prožívali období, která pro nás představují už jen kapitoly v učebnicích dějepisu (zajímavé jsou např. vzpomínky na druhou světovou válku).

Na tvorbě ČJA se podílelo několik generací českých dialektologů (knižně vyšel 19922011), práce však definitivně neskončily - na webových stránkách Ústavu pro jazyk český

\footnotetext{
1 Existují různé lokální a regionální laické nářeční slovníky, webové stránky psané místním dialektem, videa o nářečích, o významu nářečních slov, o územních nářečních diferencích.
} 
byl postupně zveřejněn v PDF verzi celý ČJA (https://cja.ujc.cas.cz/) a v HTML verzi (https://cja.ujc.cas.cz/e-cja/) jsou zatím dostupné první čtyři svazky.

Připravuje se interaktivní propojení ČJA s lexikografickými díly vznikajícími v dialektologickém oddělení a gramatická data získaná při výzkumech pro ČJA jsou využívána při zpracovávání projektu Nářeči českého jazyka interaktivně. Dokumentace a zpř́stupnění mizejícího jazykového dědictví jako nedilné součásti regionálních identit (2020-2022). Jedná se o společný úkol brněnských dialektologů a geoinformatiků ${ }^{2}$ Univerzity Palackého v Olomouci, jež položí základ interaktivní celoúzemní nářeční gramatice, jednotlivé gramatické jevy budou prezentovány na mapách a doloženy textovými a zvukovými nářečními ukázkami³.

Etapa lexikografického zpracování nářečního materiálu byla v dialektologickém oddělení Ústavu pro jazyk český započata roku 2011 zahájením prací na celonárodním Slovníku nářeči českého jazyka (dále SNČJ). Cílem je podat ucelený pohled na lexikum českých dialektů, které v souvislosti se změnami způsobu života nenávratně mizí.

Slovník je vytvářen ve speciálním počítačovém programu a díky tomu vzniká podklad jak pro elektronickou, tak pro tištěnou podobu. Je koncipován jako interaktivní a bude propojen s dalšími výstupy dialektologického oddělení. Slovníková hesla jsou pro potřeby odborné i laické veřejnosti postupně zveřejňována na webových stránkách Ústavu pro jazyk český (https://sncj.ujc.cas.cz/), prozatím je dostupných více než 10 tisíc hesel s náslovím A-Č.

Materiálovou základnou pro SNČJ jsou písemné nářeční doklady uchovávané v archivu dialektologického oddělení Ústavu pro jazyk český, jež byl založen již v roce 1952. Základ archivu tvoří excerpce z tištěných i rukopisných prací dialektologického zaměření z různých oblastí Česka (monografie, slovníky, soukromé sběry, časopisecké příspěvky, rukopisné záznamy získávané od 80 . let 19 . století). Do archivu bylo zařazeno také zhruba 25 tisíc slov a slovních forem z ČJA, další materiál je doplňován z regionálních slovníků, z diplomových i disertačních prací dialektologického zaměření. Významnou součást archivu představují též excerpta $\mathrm{z}$ autentických nářečních promluv, získaných jednak během terénních výzkumů pro ČJA, jednak při dalších výzkumech, na které dialektologové pravidelně vyjíždějí.

I v archivování nářečních materiálů se využívají nové technické možnosti. Dříve byl materiál evidován $\mathrm{v}$ podobě excerpčních kartotéčních lístků (př́slušný nářeční výraz je v některých př́padech kromě exemplifikace přiblížen i ilustrativním nákresem s popiskami, viz obrázek 1).

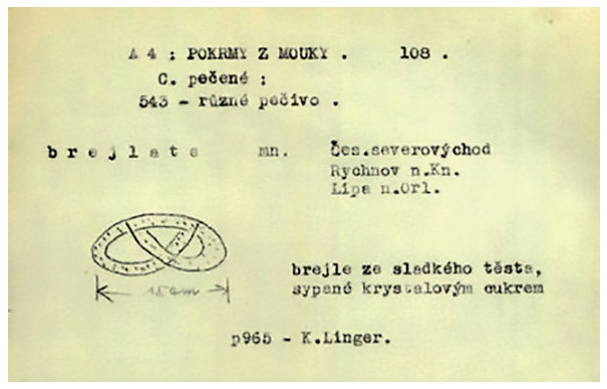

Il. 1. Excerpční lístek, výraz brejlata

\footnotetext{
2 Prvním společným výstupem je Atlas náreči českého jazyka - krácení vokáli̊ (ANČJ), v němž je představeno šestnáct vybraných map z 5 . dílu ČJA v nové grafické podobě a zcela nové mapy typizace a regionalizace. Díky geoinformatickému zpracování je nářeční materiál zobrazen inovativním zpưsobem, který umožní hlubší analýzy v rámci jazykovězeměpisných bádání.
}

3 Podrobněji viz Stupňánek 2020. 


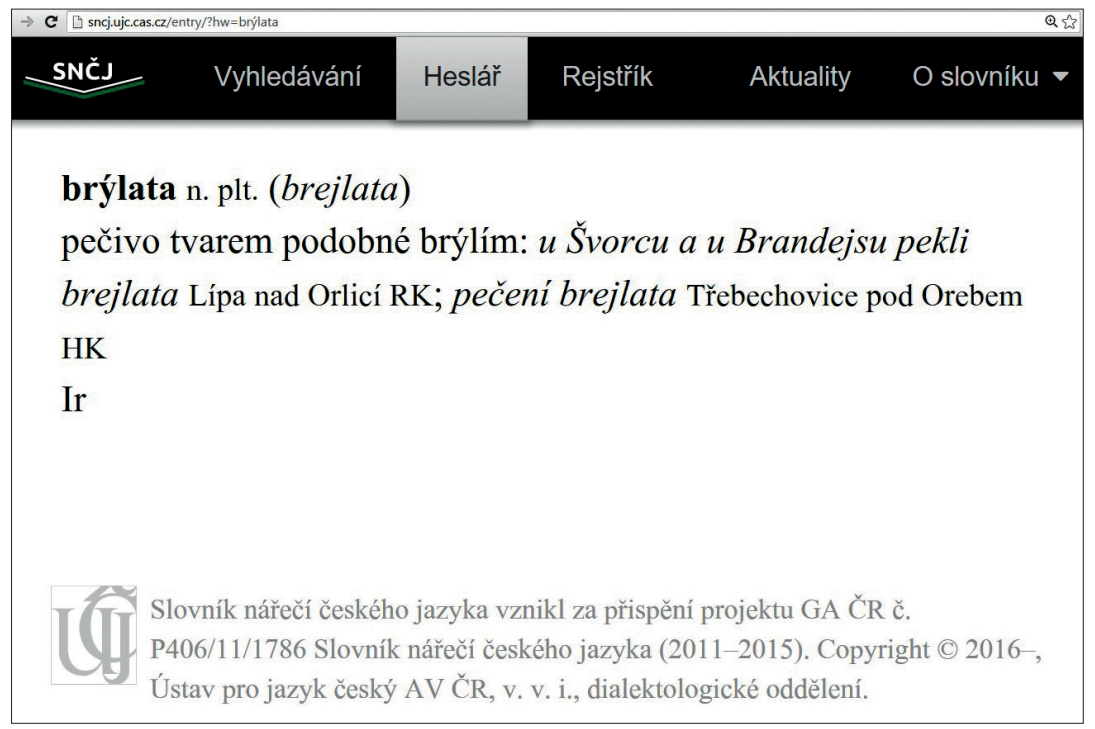

Il. 2. Slovnik náreči českého jazyka, heslo brýlata (https://sncj.ujc.cas.cz/)

Dnes jsou nově získané materiály ukládány v elektronické podobě. Lístkový archiv byl digitalizován a v současné době se hledají způsoby, jak převést do elektronické podoby rukopisné materiály ze starších nářečních výzkumů tak, aby bylo možné využivat funkce automatického vyhledávání.

Zájemcům o česká nářečí z řad odborné i laické veřejnosti, pedagogům a jejich žákům jsou na internetu $\mathrm{k}$ dispozici další výsledky práce brněnských dialektologů. $\mathrm{Na}$ mapě českých nářečí Jak se kde mluví (http://www.ujc.cas.cz/sd/publikace/knizni/dialektologicke-odd-publikace/Mapa-ceskych-nareci.html) jsou přehledně představeny nářeční skupiny, podskupiny a typy spolu s nářečními znaky charakteristickými pro př́íslušnou oblast. V edici Věda kolem nás (řada Pro všední den; http://www.vedakolemnas.cz/pro-vsedni-den/) vyšly dva propagační sešity, a to Slovník náreči českého jazyka (tiskem 2016), jenž popisuje vznikající SNČJ, a Nářeči dřive a nyní. Český jazykový atlas (tiskem 2015), přinášející jednak informace o vzniku ČJA, jednak ukázky nářečních promluv ze všech nářečních skupin, doplněné nejcharakterističtějšími rysy dané nářeční oblasti.

Onomastickým projektem dialektologického oddělení je Slovník pomistních jmen na Moravě a ve Slezsku (dále SPJMS) ${ }^{4}$, který v elektronické podobě vzniká od roku 2005 (https://spjms.ujc.cas.cz). Sběr anoikonym (pomístních jmen) probíhal v 60.-80. letech 20. století prostřednictvím soupisové ankety, terénního výzkumu a též pomocí studentských prací (seminárních, diplomových, disertačních). Cílem bylo shromáždit stará i novější anoikonyma $\mathrm{z}$ každé obce s převahou obyvatelstva české národnosti. V archivu dialektologického oddělení je uloženo zhruba 225 tisíc záznamů.

${ }^{4} \mathrm{~V}$ onomastickém oddělení Ústavu pro jazyk český Akademie věd české republiky vzniká Slovník pomistnich jmen $v$ Čechách (https://spjc.ujc.cas.cz/). 
Anoikonyma jsou živou součástí komunikačních aktivit obyvatelstva, slouží k identifikaci objektů, usnadňují lidem orientaci v prostředí, ve kterém se pohybují a pracují, ale jsou složkou velmi proměnlivou. Vzhledem k tomu, že se od dob výzkumu podstatně změnil způsob života (lidé tráví v krajině mnohem méně času než předcházející generace) a vzhled krajiny (např. dřívější pole a louky jsou dnes zastavěny), velké množství anoikonym zachycených před zhruba 40 lety již zejména dnešní nejmladší generace nezná. Anoikonyma dokládají hláskoslovný a tvaroslovný charakter místních nářečí, často uchovávají nářeční lexémy, ale svědčí i o mezijazykových kontaktech. Naším úkolem je tedy uchovat je i pro další generace jako cenný pramen pro poznání historie jazyka a pro zkoumání vývoje společnosti.

Po interaktivním propojení SPJMS, ČJA a SNČJ bude zprostředkován komplexní pohled na materiál shromážděný v archivech dialektologického oddělení (v současné době jsou již funkční odkazy na ČJA ve SPJMS, viz např. heslo Babulka), viz https://spjms.ujc. cas.cz/entry/4410)..

Pracovníci dialektologického oddělení Ústavu pro jazyk český se významnou měrou zapojují též do projekti̊ nadnárodních. Výsledkem kooperace s dalšími národními kolektivy jazykovědců akademických a univerzitních pracovišt’ jsou jednotlivé svazky Evropského jazykového atlasu (Atlas linguarum Europae; dále ALE; vzniká pod patronací UNESCO) a nejvýznamnějšího projektu slovanské jazykovědy Slovanského jazykového atlasu (Общеславянский лингвистический атлас. Atlas Linguistique Slave. Slavic Linguistic Atlas; dále OLA). Pracovnice dialektologického oddělení zpracovaly pro již vydaný, devátý svazek ALE (ALE I.9) mapu a komentář játra (I-181 foie / liver) a do plánovaných svazků mapy a komentáře zub (ALE I.10, I-159 dent / tooth) a včela (ALE I.11, I-342 abeille / bee). V dialektologickém oddělení byl k vydání připraven 9 . svazek foneticko-gramatické série OLA Reflexy *tort, *tolt, *tert, *telt, *ort, *olt (na 79 mapách jsou představeny výsledky metatezí likvid v dialektech slovanských jazyků; tiskem 2019, je též dostupný na http://slavatlas.org/files/publications/atlasy/ola9a/ola-9.pdf).

I výsledky mezinárodní spolupráce dialektologů zajímají veřejnost, proto jsou pořádány přednášky pro laiky a pro studenty vysokých škol. V edici Věda kolem nás (řada Prostory společné paměti; http://www.vedakolemnas.cz/prostory-spolecne-pameti/, též tiskem 2020) byl vydán propagační sešit Slovanský jazykový atlas.

Význam výše uvedených děl a nářečního materiálu uloženého v archivu dialektologického oddělení stále roste, protože každodenní mluva nářečních mluvčích je v 21. století velmi odlišná od mluvy předcházejících generací. Způsob života se během uplynulého půlstoletí výrazně proměnil, nepoužíváme předměty a pracovní postupy, jež byly běžné např̀. ještě 60. letech 20. století, tedy v době výzkumů pro Český jazykový atlas, takže i mnohé výrazy spojené s tehdejšími reáliemi již upadly v zapomnění, hláskové a morfologické diference se postupně stírají. Vše je uchováno jen díky záznamům z nářečních výzkumů. Výrazný ústup nářečí lze pozorovat zejména u současné mladé generace. Slova, která jsou součástí mluvy nejstarší generace, střední generace zčásti používá též aktivně, zčásti je má alespoň uložena ve svém povědomí. Tatáž slova však nejmladší mluvčí už mnohdy neznají ani pasivně.

Během výzkumů a při kontaktu se studenty se však setkáváme i s takovými jedinci, kteří si uvědomují, že nářečí je součástí jejich regionální identity a každodenního života a že je potřeba své nářečí chránit a udržovat, aby bylo zachováno i pro další generace. 
Úkolem dialektologů je tedy nejen zpracovat archivovaný nářeční materiál, publikovat výsledky své práce a seznamovat s nimi veřejnost, ale také pokračovat v obohacování archivu o současné záznamy mluvených projevů, protože i ty se časem stanou cenným svědectvím o stavu dnešní každodenní běžné mluvy. Zajímavé výsledky by zcela jistě přinesl nový celoúzemní nářeční výzkum a jeho zpracování pomocí současných metod a prostředků a komparace s rezultáty výzkumů minulých ${ }^{5}$.

\section{Literatura}

ALE, Šipková M., Čižmárová L. (2015), Komentář k mapě: 1.102 Foie (QI: 181). Carte de motivations; Mapa a legenda: 1.102 Foie (QI: 181), [in:] Atlas linguarum Europae, vol. I: Neuvième fascicule: Commentaires, sv. 9, red. N. Saramandu, M. Nevaci, I. Geană, Bucureşti, s. 391-426; 206-223.

ANČJ, Ireinová M., Voženílek V., Pospíšil M., Koníček J., Vondráková A. (2020), Atlas nářeči českého jazyka - krácení vokálů, Olomouc.

Čižmárová L., Kloferová S., Šipková M., Jak se kde mluví, http://www.ujc.cas.cz/sd/publikace/ knizni/dialektologicke-odd-publikace/Mapa-ceskych-nareci. html, 10.12.2020.

ČJA, Český jazykový atlas (HTML verze), https://cja.ujc.cas.cz/e-cja/, 10.12.2020.

ČJA, Český jazykový atlas (PDF verze), https://cja.ujc.cas.cz/, 10.12.2020.

Ireinová M., Konečná H. (2015), Nářeči dřive a nyní. Český jazykový atlas, Praha.

Ireinová M., Konečná H. (2016), Slovník nářeči českého jazyka, Praha.

Ireinová M., Přadková P., eds. (2019), Obščeslavjanskij lingvističeskij atlas, serija fonetikogrammatičeskaja, vypusk 9. Refleksy *tort, *tolt, *tert, *telt, *ort, *olt, Praha.

OLA, Общеславянский лингвистический атлас [Obščeslavjanskij lingvističeskij atlas], http:// slavatlas.org/, 10.12.2020.

Přadková P. (2020), Slovanský jazykový atlas, Praha.

SNČJ, Slovnik nářeči českého jazyka, https://sncj.ujc.cas.cz/, 10.12.2020.

SPJMS, Slovnik pomistních jmen na Moravě a ve Slezsku, https://spjms.ujc.cas.cz/, 10.12.2020.

Stupňánek B. (2020), Metodologie interaktivního mapového zpracování systematických gramatických struktur, „Gwary Dziś”, t. 12, s. 269-279.

\footnotetext{
${ }_{5}$ Příspěvek vznikl na základě řešení projektu č. DG20P02OVV029 Nářeči českého jazyka interaktivně. Dokumentace a zpř́stupněni mizejicího jazykového dědictví jako nedilné součásti regionálních identit; poskytovatel podpory Ministerstvo kultury České republiky, Program NAKI II. Práce použivá také data, která poskytuje výzkumná infrastruktura LINDAT/CLARIAH-CZ (https://lindat.cz) podporovaná Ministerstvem školství, mládeže a tělovýchovy České republiky (projekt č. LM2018101).
} 